Review Article

\title{
A Bibliometric Analysis of Global COVID-19 Research
}

\author{
Shaheer Ahmed ${ }^{1, *}$, Usama Waqar ${ }^{2}$, Kantesh Kumar Lohana ${ }^{2}$, Daniyal Ali Khan ${ }^{2}$ \\ ${ }^{1}$ Islamabad Medical \& Dental College, Shaheed Zulfiqar Ali Bhutto Medical University, Islamabad, Pakistan. \\ ${ }_{2}^{2}$ Medical College, Aga Khan University, Karachi, Pakistan.
}

\begin{abstract}
Background: Coronavirus disease 2019 (COVID-19) has influenced all continents, prompting extraordinary efforts on worldwide research and publications to alleviate the crisis.
\end{abstract}

Methods: We conducted a bibliometric review using Scopus to assess its impact on global scientific production. We searched for the following terms in titles, abstracts, and keywords to identify relevant literature published until $9^{\text {th }}$ January 2021: 2019 novel coronavirus, 2019-nCoV, SARS-CoV-2, COVID-19, coronavirus disease-19, coronavirus disease 2019.

Results: Our results retrieved 86,624 documents from 159 countries with the USA, China, and UK being the top three contributors. Overall citation count was 769,811 with documents from China being cited most. In terms of h-index, China, USA, and UK ranked highest respectively.

Conclusion: Most publications were associated with developed countries that were hit the earliest and/or hardest. This impact on scientific publications was less pronounced in developing countries like Pakistan, highlighting the immediate need to support and facilitate research on COVID-19 in these countries.

Keywords: COVID-19, Research, Bibliometric analysis, Publications, SARS-CoV-2, Developing countries, Research and development.

\section{INTRODUCTION}

An outbreak of viral pneumonia of unknown origin was reported from Wuhan, China, at the end of 2019, which was identified as a novel beta coronavirus (2019-nCoV) [1]. This was later declared as a pandemic by WHO following its spread outside China [2]. As of $9^{\text {th }}$ January 2021, 87,273,380 cases of coronavirus disease 2019 (COVID-19) and 1,899,440 associated deaths have been confirmed worldwide [3].

The crisis has overwhelmed the existing healthcare resources owing to the large patient influx [4]. This is also inflicting a tremendous mental health burden, especially on frontline healthcare workers [5]. This has prompted the global authorities to take extreme measures aimed at breaking the transmission lines, including worldwide travel restrictions, institutional and business closures, lockdowns, etc. However, these mitigation measures are adversely affecting international economics, leading towards recession [6].

This situation has caused significant concern, prompting extraordinary efforts on worldwide research and publications to alleviate the crisis. We carried out a bibliometric analysis to investigate the impact of COVID-19 on global scientific production.

\section{METHODS}

Our methodology was influenced from previous bibliometric analyses [7-10]. We used Scopus abstract and citation

*Address correspondence to this author at the Department of Islamabad Medical \& Dental College, Shaheed Zulfiqar Ali Bhutto Medical University, Islamabad, Pakistan. Email: shaheershk.35@gmail.com database by Elsevier. Scopus was selected based on its wider coverage of journals than other potential candidates [11]. Journal impact factors were extracted from Web of Science Journal Citation Report 2019 (JCR). WHO Corona Virus Disease Dashboard was used to collect data on COVID-19 cases and deaths [3].

Our search strategy involved collecting data on indexed articles published till $9^{\text {th }}$ January 2020 using the following search query: (((TITLE-ABS-KEY("COVID 19*") OR TITLE-ABS-KEY(\{2019 novel coronavirus* $\})$ OR TITLE-ABS-KEY (\{SARS-CoV- $2 *\})$ OR TITLE-ABS-KEY("2019-nCoV*") OR TITLE-ABS-KEY (\{coronavirus disease 2019*\}) OR TITLE-ABS-KEY $(\{$ coronavirus disease-19*\})))).

We analyzed the following bibliometric indicators: number of publications, language, publication distribution by countries and territories, affiliated institutions, funding sponsors, authors, journals, international collaboration, impact factor, citation count, and h-index (number of papers with citations $\geq$ h) [12].

All data were collected and organized using Microsoft Excel 2016. IBM SPSS Version 24 was employed for statistical analyses. Shapiro-Wilk test for normality was performed on continuous variables, which were found to have non-parametric distribution. Descriptive analyses are presented with continuous variables reported by their medians (interquartile ranges) and categorial variables by their frequencies (percentages). Pearson correlation coefficients were computed to assess the relationships of publication distribution by coun- 
try/territory with number of COVID-19 cases and deaths.

\section{RESULTS}

We retrieved 86624 documents with an overall citation count of 769,811 . There were 50067 articles, corresponding to $57.80 \%$ of the total scientific output, followed by letters $(14.36 \%)$, reviews $(11.82 \%)$, notes $(6.65 \%)$, and editorials $(5.37 \%)$. The remaining $3.99 \%$ comprised of short surveys, conference papers, data papers, book chapters, and conference reviews. $69879(80.67 \%)$ of these documents were made publicly available as open access. These documents were published in 38 languages, with English (94.12\%), Spanish $(2.43 \%)$, and Chinese $(1.33 \%)$ being the most common.
These documents originated from 159 countries and territories. USA $(25.37 \%)$, China $(11.27 \%)$, and UK $(10.70 \%)$ ranked highest in terms of number of publications (Table 1). With respect to h-index, China, USA, and UK ranked highest $(212,177$, and 120 respectively). Publications from China had most citations (250203), followed by USA, UK, and Italy (194306, 85067, and 71608 respectively). USA and UK had collaborated with the highest number of countries (159 countries), followed by France (150). Among the continents, Europe ranked first in terms of publications, followed by Asia, North America, South America, Oceania, and Africa, respectively.

Table 1. Pakistan and its Neighboring Countries along with Top 10 Countries with Respect to Number of Publications on COVID-19 in Scopus-Indexed Journals.

\begin{tabular}{|c|c|c|c|c|c|}
\hline Rank /159 & Country & $\begin{array}{c}\text { Publications } \\
\text { (percentage of total) }\end{array}$ & h-Index & $\begin{array}{l}\text { Citations (median; } \\
\text { interquartile range) }\end{array}$ & $\begin{array}{c}\text { Number of Countries } \\
\text { Collaborated with }\end{array}$ \\
\hline 1 & USA & $21975(25.37)$ & 177 & $194306(3 ; 9)$ & 159 \\
\hline 3 & UK & $9265(10.70)$ & 120 & $85067(1 ; 4)$ & 159 \\
\hline 4 & Italy & 7958 (9.19) & 106 & $71608(1 ; 5)$ & 146 \\
\hline 6 & Spain & $3741(4.32)$ & 63 & $24045(0 ; 3)$ & 138 \\
\hline 7 & Canada & $3676(4.24)$ & 74 & $30119(1 ; 4)$ & 142 \\
\hline 8 & Germany & $3386(3.91)$ & 83 & $41695(1 ; 4)$ & 141 \\
\hline 9 & France & $3350(3.87)$ & 80 & $34525(1 ; 5)$ & 150 \\
\hline 10 & Australia & $3302(3.81)$ & 66 & $28278(1 ; 4)$ & 143 \\
\hline
\end{tabular}

Worse-affected countries tended to have a greater number of publications. Upon bivariate correlation analyses, number of cases (Fig. 1) and deaths (Fig. 2) in a country varied signifi-

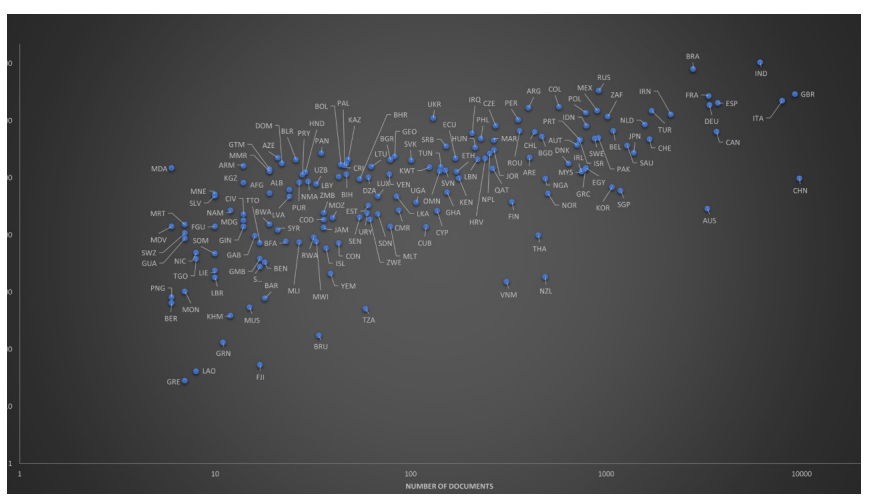

Fig. (1). Country-Wise COVID-19 Cases and Publications in Scopus-Indexed Journals. cantly with number of documents produced by that county ( $\mathrm{r}$ $=0.825$ and 0.799 respectively; $\mathrm{p}<0.001)$.

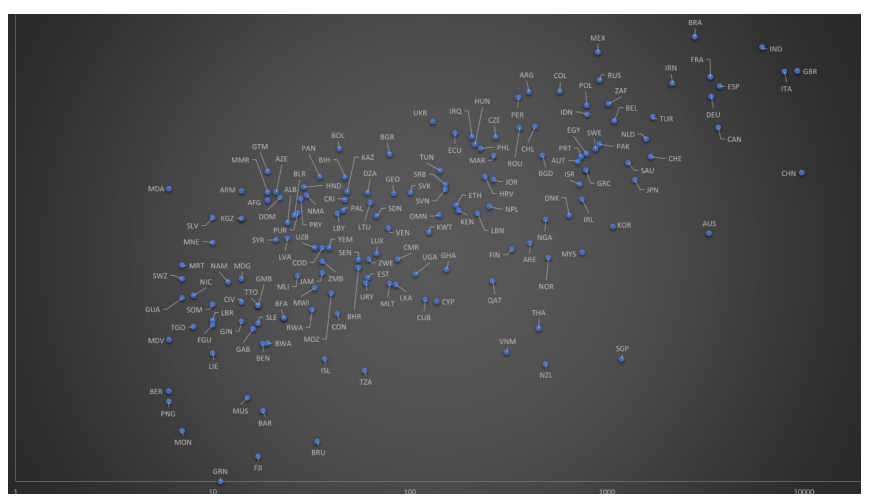

Fig. (2). Country-Wise COVID-19 Associated Deaths and Publications in Scopus-Indexed Journals.

$\mathrm{AFG}=$ Afghanistan. $\mathrm{ALB}=\mathrm{Albania} . \mathrm{DZA}=$ Algeria. $\mathrm{ARG}=$ Argentina. $\mathrm{ARM}=$ Armenia. $\mathrm{AUS}=$ Australia $. \mathrm{AUT}=\mathrm{Austria} . \mathrm{AZE}=\mathrm{Azerbaijan} . \mathrm{BHR}=\mathrm{Bahrain}$. $\mathrm{BGD}=$ Bangladesh. $\mathrm{BAR}=$ Barbados. $\mathrm{BLR}=$ Belarus. $\mathrm{BEL}=$ Belgium. $\mathrm{BEN}=$ Benin. $\mathrm{BER}=$ Bermuda. $\mathrm{BOL}=$ Bolivia. $\mathrm{BIH}=$ Bosnia and Herzegovina. $\mathrm{BWA}=\mathrm{Botswa}-$ na. 
$\mathrm{BRA}=$ Brazil. $\mathrm{BRU}=$ Brunei Darussalam. BGR=Bulgaria. $\mathrm{BFA}=$ Burkina Faso. $\mathrm{KHM}=$ Cambodia. $\mathrm{CMR}=\mathrm{Cameroon} . \mathrm{CAN}=\mathrm{Canada} . \mathrm{CHL}=\mathrm{Chile} . \mathrm{CHN}=\mathrm{China}$. $\mathrm{COL}=$ Colombia. $\mathrm{CON}=$ Congo. $\mathrm{CRI}=$ Costa Rica. $\mathrm{CIV}=$ Côte d'Ivoire. $\mathrm{HRV}=$ Croatia. $\mathrm{CUB}=\mathrm{Cuba} . \mathrm{CYP}=\mathrm{Cyprus}$. CZE=Czech Republic. $\mathrm{COD}=\mathrm{Democratic}$ Republic of the Congo. DNK=Denmark. DOM=Dominican Republic. ECU=Ecuador. EGY=Egypt. SLV=El Salvador. EST=Estonia. ETH=Ethiopia. FJI=Fiji. FIN=Finland. FRA=France. FGU $=$ French Guiana. GAB $=$ Gabon. GMB $=$ Gambia. GEO=Georgia. $\mathrm{DEU}=\mathrm{Germany}$. GHA=Ghana. GRC=Greece. GRE=Greenland. $\mathrm{GRN}=$ Grenada. GUA=Guadeloupe. GTM=Guatemala. $\mathrm{GIN}=$ Guinea. $\mathrm{HND}=$ Honduras. HUN=Hungary. ISL=Iceland. IND=India. IDN=Indonesia. $I R N=I r a n . \quad I R Q=I r a q . \quad I R L=I r e l a n d . \quad I S R=I s r a e l . \quad I T A=I t a l y . \quad J A M=J a m a i c a . \quad J P N=J a p a n . \quad J O R=J o r d a n . \quad K A Z=K a z a k h s t a n . \quad K E N=K e n y a . \quad K W T=K u w a i t$. KGZ=Kyrgyzstan. LAO=Lao People's Democratic Republic. LVA=Latvia. LBN=Lebanon. LBR=Liberia. LBY=Libya. LIE=Liechtenstein. LTU=Lithuania. LUX=Luxembourg. MDG=Madagascar. MWI=Malawi. MYS=Malaysia. MDV=Maldives. MLI=Mali. MLT=Malta. MRT=Mauritania. MUS=Mauritius. MEX=Mexico. $\mathrm{MDA}=$ Republic of Moldova. $\mathrm{MON}=$ Monaco. MNE=Montenegro. MAR=Morocco. MOZ=Mozambique. MMR=Myanmar. NAM=Namibia. $\mathrm{NPL}=$ Nepal. $\mathrm{NLD}=$ Netherlands. $\mathrm{NZL}=\mathrm{New} Z$ Zealand. $\mathrm{NIC}=$ Nicaragua. $\mathrm{NGA}=$ Nigeria. $\mathrm{NMA}=$ North Macedonia. NOR=Norway. OMN=Oman. $\mathrm{PAK}=\mathrm{Pakistan}$. $\mathrm{PAL}=$ Palestine. $\mathrm{PAN}=$ Panama. $\mathrm{PNG}=$ Papua New Guinea. $\mathrm{PRY}=$ Paraguay. $\mathrm{PER}=\mathrm{Peru} . \mathrm{PHL}=\mathrm{Philippines} . \mathrm{POL}=\mathrm{Poland}$. PRT=Portugal. $\mathrm{PUR}=\mathrm{Puerto}$ Rico.

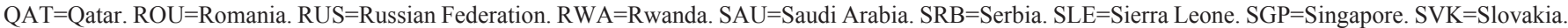
$\mathrm{SVN}=$ Slovenia. SOM=Somalia. ZAF=South Africa. KOR=South Korea. ESP=Spain. LKA=Sri Lanka. SDN=Sudan. SWZ=Swaziland. SWE=Sweden. $\mathrm{CHE}=$ Switzerland. $\mathrm{SYR}=$ Syrian Arab Republic. TZA=United Republic of Tanzania. THA=Thailand. TGO=Togo. TTO=Trinidad and Tobago. TUN=Tunisia. TUR=Turkey. UGA=Uganda. UKR=Ukraine. ARE=United Arab Emirates. GBR=United Kingdom. USA=United States of America. URY=Uruguay. UZB=Uzbekistan. VEN=Venezuela. VNM=Viet Nam. YEM=Yemen. ZMB=Zambia. ZWE=Zimbabwe.

Author Elisabeth Mahase affiliated with the BMJ had published most documents (130; h-index=14; Table 2) while Huang et al. had published the highest-cited document (10540 citations) in Lancet (Table 3) [13]. The remaining highest-cited documents were mostly published in the Lancet, New England Journal of Medicine (NEJM), and Journal of the
American Medical Association (JAMA). International Journal of Environmental Research and Public Health (760), Journal of Medical Virology, BMJ Clinical Research Ed, PLoS One, and BMJ had published 3.75\% of Scopus-indexed documents (Table 4).

Table 2. Top 10 Authors with Respect to Number of Publications on COVID-19 in Scopus-Indexed Journals.

\begin{tabular}{|c|c|c|c|c|c|}
\hline Rank & Author & Affiliation & $\begin{array}{c}\text { Publications } \\
\text { (percentage of total) }\end{array}$ & $\begin{array}{c}\text { h- } \\
\text { Index }\end{array}$ & $\begin{array}{l}\text { Citations (median; } \\
\text { interquartile range) }\end{array}$ \\
\hline 1 & Elisabeth Mahase & BMJ, UK & $130(0.15)$ & 14 & $809(1 ; 4)$ \\
\hline 3 & Giuseppe Lippi & University of Verona, Italy & $85(0.10)$ & 26 & $3258(4 ; 33)$ \\
\hline 4 & Viroj Wiwanitkit & Dr. DY Patil University, India & $81(0.10)$ & 10 & $450(1 ; 4)$ \\
\hline 6 & Abi Rimmer & BMJ, UK & $62(0.07)$ & 6 & $99(0 ; 2)$ \\
\hline 7 & Alfonso J. Rodriguez-Morales & $\begin{array}{c}\text { Technological University of Pereira, } \\
\text { Colombia }\end{array}$ & $61(0.07)$ & 17 & $1445(6 ; 22)$ \\
\hline 8 & Nima Rezaei & $\begin{array}{c}\text { Tehran University of Medical Sciences, } \\
\text { Iran }\end{array}$ & $57(0.07)$ & 13 & $522(3 ; 10)$ \\
\hline
\end{tabular}

Table 3. Top 25 Highest-Cited Documents on COVID-19 in Scopus-Indexed Journals.

\begin{tabular}{|c|c|l|c|c|}
\hline Rank & Author (s) & \multicolumn{1}{|c|}{ Title } & Journal & Citation \\
\hline 1 & Huang et al. $[13]$ & $\begin{array}{l}\text { Clinical features of patients infected with 2019 novel } \\
\text { coronavirus in Wuhan, China }\end{array}$ & The Lancet & 10540 \\
\hline 2 & Guan et al.[14] & $\begin{array}{l}\text { Clinical characteristics of coronavirus disease 2019 } \\
\text { in China }\end{array}$ & $\begin{array}{c}\text { New England Journal } \\
\text { of Medicine }\end{array}$ & 7007 \\
\hline 3 & Wang et al.[15] & $\begin{array}{l}\text { Clinical Characteristics of 138 Hospitalized Patients } \\
\text { with 2019 Novel Coronavirus-Infected Pneumonia } \\
\text { in Wuhan, China }\end{array}$ & $\begin{array}{c}\text { JAMA - Journal of the } \\
\text { American Medical } \\
\text { Association }\end{array}$ & 6077 \\
\hline 4 & Zhou F et al.[16] & $\begin{array}{l}\text { Clinical course and risk factors for mortality of adult } \\
\text { inpatients with COVID-19 in Wuhan, China: } \\
\text { a retrospective cohort study }\end{array}$ & The Lancet & 5758 \\
\hline
\end{tabular}


Continued...

\begin{tabular}{|c|c|c|c|c|}
\hline Rank & Author (s) & Title & Journal & Citation \\
\hline 5 & Zhu et al.[17] & $\begin{array}{l}\text { A novel coronavirus from patients with } \\
\text { pneumonia in China, } 2019\end{array}$ & $\begin{array}{c}\text { New England Journal } \\
\text { of Medicine }\end{array}$ & 5749 \\
\hline 6 & Chen et al.[18] & $\begin{array}{l}\text { Epidemiological and clinical characteristics of } 99 \\
\text { cases of } 2019 \text { novel coronavirus pneumonia } \\
\text { in Wuhan, China: a descriptive study }\end{array}$ & The Lancet & 5252 \\
\hline 7 & Zhou P et al.[19] & $\begin{array}{l}\text { A pneumonia outbreak associated with a new } \\
\text { coronavirus of probable bat origin }\end{array}$ & Nature & 4298 \\
\hline 8 & Wu et al.[20] & $\begin{array}{l}\text { Characteristics of and Important Lessons from the } \\
\text { Coronavirus Disease } 2019 \text { (COVID-19) Outbreak } \\
\text { in China: Summary of a Report of } 72314 \text { Cases from } \\
\text { the Chinese Center for Disease Control and Prevention }\end{array}$ & $\begin{array}{l}\text { JAMA - Journal of the } \\
\text { American Medical } \\
\text { Association }\end{array}$ & 4093 \\
\hline 9 & Li et al.[21] & $\begin{array}{l}\text { Early transmission dynamics in Wuhan, China, of } \\
\text { novel coronavirus-infected pneumonia }\end{array}$ & $\begin{array}{l}\text { New England Journal } \\
\text { of Medicine }\end{array}$ & 3900 \\
\hline 10 & Hoffmann et al.[22] & $\begin{array}{l}\text { SARS-CoV-2 Cell Entry Depends on ACE2 and } \\
\text { TMPRSS2 and Is Blocked by a Clinically Proven } \\
\text { Protease Inhibitor }\end{array}$ & Cell & 3156 \\
\hline 11 & Lu et al.[23] & $\begin{array}{l}\text { Genomic characterization and epidemiology of } 2019 \\
\text { novel coronavirus: implications for virus origins and } \\
\text { receptor binding }\end{array}$ & The Lancet & 2852 \\
\hline 12 & Chan et al.[24] & $\begin{array}{l}\text { A familial cluster of pneumonia associated with the } \\
2019 \text { novel coronavirus indicating person-to-person } \\
\text { transmission: a study of a family cluster }\end{array}$ & The Lancet & 2548 \\
\hline 13 & Xu et al.[25] & $\begin{array}{l}\text { Pathological findings of COVID-19 associated with } \\
\text { acute respiratory distress syndrome }\end{array}$ & $\begin{array}{c}\text { The Lancet } \\
\text { Respiratory Medicine }\end{array}$ & 2356 \\
\hline 14 & Mehta et al.[26] & $\begin{array}{l}\text { COVID-19: consider cytokine storm syndromes } \\
\text { and immunosuppression }\end{array}$ & The Lancet & 2281 \\
\hline 15 & Wang et al.[27] & $\begin{array}{l}\text { Remdesivir and chloroquine effectively inhibit the } \\
\text { recently emerged novel coronavirus (2019-nCoV) } \\
\text { in vitro }\end{array}$ & Cell Research & 1989 \\
\hline 16 & Wu et al.[28] & $\begin{array}{l}\text { A new coronavirus associated with human } \\
\text { respiratory disease in China }\end{array}$ & Nature & 1917 \\
\hline 17 & Holshue et al.[29] & $\begin{array}{l}\text { First case of } 2019 \text { novel coronavirus in the } \\
\text { United States }\end{array}$ & $\begin{array}{c}\text { New England Journal } \\
\text { of Medicine }\end{array}$ & 1888 \\
\hline 18 & Wu et al.[30] & $\begin{array}{l}\text { Risk Factors Associated with Acute Respiratory } \\
\text { Distress Syndrome and Death in Patients with } \\
\text { Coronavirus Disease } 2019 \text { Pneumonia in Wuhan,China }\end{array}$ & $\begin{array}{l}\text { JAMA Internal } \\
\text { Medicine }\end{array}$ & 1887 \\
\hline 19 & Gautret et al.[31] & $\begin{array}{l}\text { Hydroxychloroquine and azithromycin as a treatment } \\
\text { of COVID-19: results of an open-label } \\
\text { non-randomized clinical trial }\end{array}$ & $\begin{array}{c}\text { International Journal } \\
\text { of Antimicrobial } \\
\text { Agents }\end{array}$ & 1758 \\
\hline 20 & Cao et al.[32] & $\begin{array}{l}\text { A trial of lopinavir-ritonavir in adults hospitalized } \\
\text { with severe COVID-19 }\end{array}$ & $\begin{array}{l}\text { New England Journal } \\
\text { of Medicine }\end{array}$ & 1645 \\
\hline 21 & Richardson et al.[33] & $\begin{array}{l}\text { Presenting Characteristics, Comorbidities, and } \\
\text { Outcomes among } 5700 \text { Patients Hospitalized with } \\
\text { COVID-19 in the New York City Area }\end{array}$ & $\begin{array}{c}\text { JAMA - Journal of the } \\
\text { American Medical } \\
\text { Association }\end{array}$ & 1584 \\
\hline 22 & Wrapp et al.[34] & $\begin{array}{l}\text { Cryo-EM structure of the } 2019-\mathrm{nCoV} \text { spike in the } \\
\text { prefusion conformation }\end{array}$ & Science & 1570 \\
\hline 23 & Zou et al.[35] & $\begin{array}{l}\text { SARS-CoV-2 viral load in upper respiratory } \\
\text { specimens of infected patients }\end{array}$ & $\begin{array}{c}\text { New England Journal } \\
\text { of Medicine }\end{array}$ & 1463 \\
\hline 24 & Mao et al.[36] & $\begin{array}{l}\text { Neurologic Manifestations of Hospitalized Patients } \\
\text { with Coronavirus Disease } 2019 \text { in Wuhan, China }\end{array}$ & JAMA Neurology & 1399 \\
\hline 25 & Corman et al.[37] & $\begin{array}{l}\text { Detection of } 2019 \text { novel coronavirus ( } 2019-\mathrm{nCoV}) \\
\text { by real-time RT-PCR }\end{array}$ & Eurosurveillance & 1391 \\
\hline
\end{tabular}


Table 4. Top 10 Journals with Respect to Number of Publications on COVID-19 in Scopus-Indexed Journals.

\begin{tabular}{|c|c|c|c|c|}
\hline Rank & Journal & $\begin{array}{c}\text { Publications } \\
\text { (percentage of total) }\end{array}$ & h - Index & Impact Factora \\
\hline 1 & International Journal of Environmental Research and Public Health & $760(0.88)$ & 26 & 2.468 \\
\hline 3 & BMJ Clinical Research Ed & $619(0.71)$ & 23 & NA \\
\hline 4 & PLoS One & $600(0.69)$ & 17 & 2.776 \\
\hline 7 & International Journal of Infectious Diseases & $431(0.50)$ & 37 & 3.538 \\
\hline 8 & Medical Hypotheses & $363(0.42)$ & 14 & 1.322 \\
\hline 9 & Sustainability Switzerland & $342(0.39)$ & 12 & 2.592 \\
\hline 10 & Science of the Total Environment & $335(0.39)$ & 43 & 5.589 \\
\hline
\end{tabular}

${ }^{a}$ The impact factors were reported from journal citation report (JCR) 2019.

Harvard Medical School in USA had most papers affiliated with it $(1466 ; 1.69 \%$ of published research indexed in Scopus; h-index=63), followed by Huazhong University of Science and Technology in China, Tongji Medical College in China, and Inserm in France (Table 5). The most prominent sponsor was the National Natural Science Foundation of China, having funded 2020 publications (h-index=105; Table 6).

Table 5. Top 10 Institutions with Respect to Number of Publications on COVID-19 in Scopus-Indexed Journals.

\begin{tabular}{|c|c|c|c|c|c|}
\hline Rank & Affiliated institution & Country & $\begin{array}{c}\text { Publications } \\
\text { (percentage of total) }\end{array}$ & h - Index & $\begin{array}{c}\text { Citations (median; } \\
\text { interquartile range) }\end{array}$ \\
\hline 1 & Harvard Medical School & USA & $1466(1.69)$ & 63 & $20311(1 ; 6)$ \\
\hline 2 & Huazhong University of Science and Technology & China & $1153(1.33)$ & 92 & $56388(2 ; 14)$ \\
\hline 3 & Tongji Medical College & China & $1093(1.26)$ & 90 & $55999(2 ; 15)$ \\
\hline 4 & Inserm & France & $1016(1.17)$ & 50 & $15371(2 ; 7)$ \\
\hline 5 & University of Toronto & Canada & $942(1.09)$ & 42 & $9095(1 ; 5)$ \\
\hline 6 & Università degli Studi di Milano & Italy & $794(0.92)$ & 46 & $11268(2 ; 8)$ \\
\hline 7 & University of Oxford & UK & $785(0.91)$ & 44 & $13536(1 ; 6)$ \\
\hline 8 & Università degli Studi di Roma La Sapienza & Italy & $773(0.89)$ & 36 & $5984(1 ; 6)$ \\
\hline 9 & University College London & UK & $731(0.84)$ & 51 & $14284(1 ; 7)$ \\
\hline 10 & Massachusetts General Hospital & USA & $679(0.78)$ & 42 & $7784(1 ; 6)$ \\
\hline
\end{tabular}

Table 6. Top 10 Funding Organizations with Respect to Number of Publications on COVID-19 in Scopus-Indexed Journals.

\begin{tabular}{|c|c|c|c|c|c|}
\hline Rank & Funding organization & Country & $\begin{array}{c}\text { Publications } \\
\text { (percentage of total) }\end{array}$ & h - Index & $\begin{array}{l}\text { Citations (median; } \\
\text { interquartile range) }\end{array}$ \\
\hline 1 & National Natural Science Foundation & China & $2020(2.33)$ & 105 & $49293(1 ; 8)$ \\
\hline 3 & National Science Foundation & USA & $441(0.51)$ & 28 & $4303(0 ; 3)$ \\
\hline 4 & National Institute for Health Research & UK & $439(0.51)$ & 41 & $11437(1 ; 5)$ \\
\hline 6 & Wellcome Trust & UK & $360(0.42)$ & 41 & $11479(3 ; 13)$ \\
\hline 7 & $\begin{array}{c}\text { Conselho Nacional de Desenvolvimento } \\
\text { Científico e Tecnológico }\end{array}$ & Brazil & $351(0.41)$ & 19 & $1337(0 ; 3)$ \\
\hline 8 & $\begin{array}{c}\text { Fundamental Research Funds for the Central } \\
\text { Universities }\end{array}$ & China & $300(0.35)$ & 30 & $4489(1 ; 5.25)$ \\
\hline
\end{tabular}




\section{DISCUSSION}

Since the start of the pandemic, COVID-19 has induced an extensive number of publications in Scopus-indexed journals relating to different aspects of the disease. We aimed to investigate the impact of the COVID-19 pandemic on scientific output globally. We highlighted the hotspots of research on this topic and determined the origin of publications relating to the pandemic in terms of countries, institutions, journals, authors, affiliated institutions, and funding organizations.

Our study demonstrated that most of the highest-cited documents were published in international journals with high impact factors. Most of the documents (80.67\%) were available as open access. This was primarily because many international organizations, publishers, and journals made all their content related to COVID-19 freely available to provide high-quality evidence to the frontline healthcare workers, policymakers, and general public [38].

We found a significant agreement between epidemiology of COVID-19 and documents published given that majority of them were from worst affected countries. USA and China have played an extensive role in COVID-19 research. This is not surprising given that the outbreak originally started in China while USA has been hit hardest [39].

The contributions of China and USA to global scientific literature can also be attributed to the extensive focus that is given to research in academic institutions within these countries. Our results revealed that among the top 30 institutions in terms of documents published, 8 were from USA and 4 from China.

We highlighted certain countries, such as Brazil, Pakistan, etc., with significant cases but insufficient contribution towards research output. Being low- and middle-income countries (LMICs), it can be suggested that they lack academic institutions and facilities necessary for research, but this is not the case. Brazil ranks second and Pakistan fifth in terms of number of operational medical schools [40]. Instead, this can be explained by the insufficient focus on academic research and limited funding opportunities available there. It is imperative to promote research in these countries for long-term sustainable development in healthcare. To cater to this, potential solutions should build upon raising research awareness, supporting institutional frameworks, promoting research impact, improving research management capacity, providing career incentives, and developing research information systems [41].

Our study reported data on COVID-19 publications in Scopus-indexed journals that had been published until 9th January 2021. Some bibliometric analyses on COVID-19 have been conducted previously, but they included fewer documents as they were conducted earlier during the pandemic [42]. Therefore, this study provided a comprehensive perspective of documents related to the COVID-19 pandemic published in Scopus-indexed journals till date.

\section{CONCLUSION}

Since the start of the pandemic, COVID-19 became the center of attention of medical research for many countries, journals, institutions, and researchers. This resulted in an enormous number of publications originating primarily from developed countries, such as USA, China, UK, Italy, and India. However, impact of COVID-19 on scientific output was observed to be limited in less developed countries, i.e., Pakistan, Brazil, etc. Considering that these countries have also incurred a significant number of cases, it is important to implement strategies to support and promote research there.

\section{AUTHORS' CONTRIBUTION}

Usama Waqar conceived the topic. Usama Waqar and Shaheer Ahmed devised the methodology. All authors collected data. Usama Waqar and Shaheer Ahmed wrote the first draft. All authors reviewed the first draft and suggested changes. The final version of the draft was approved by all authors for publication.

\section{CONFLICT OF INTEREST}

Declared none.

\section{ACKNOWLEDGEMENTS}

Declared none.

\section{REFERENCES}

[1] Zhu N, Zhang D, Wang W, et al. A novel coronavirus from patients with pneumonia in China, 2019. New Engl J Med 2020; 382(8): 727-33. DOI: 10.1056/NEJMoa2001017

[2] WHO: Rolling updates on coronavirus disease (COVID-19). Available at: https://www.who.int/emergencies/diseases/novel-coronavirus-2019/events-as-they-happen; [Accessed 12, July 2020].

[3] WHO: WHO Coronavirus Disease (COVID-19) Dashboard. Available at: https://covid19.who.int/table. [Accessed 9, January 2021].

[4] Al Jazeera: As coronavirus spreads in Europe, hospitals are overwhelmed. Available at: https:/www.aljazeera.com/news/2020/03/coronavirus-spreads-europe-hospitals-overwhelmed-200325072333193.html?xif. [Accessed 21, August 2020].

[5] Greenberg N, Docherty M, Gnanapragasam S, Wessely S. Managing mental health challenges faced by healthcare workers during covid-19 pandemic. BMJ 2020; 368: m1211. 
DOI: $10.1136 /$ bmj.m1211

[6] Gourinchas P-O. Flattening the pandemic and recession curves. In: Baldwin R, Beatrice di Mauro W, Eds. Mitigating the COVID Economic Crisis: Act Fast and Do Whatever. London: CEPR Press 2020.

[7] Zyoud SeH, Al-Jabi SW, Sweileh WM. Bibliometric analysis of scientific publications on waterpipe (narghile, shisha, hookah) tobacco smoking during the period 2003-2012. TID 2014; 12(1): 7. DOI: 10.1186/1617-9625-12-7

[8] Sa'ed HZ, Al-Jabi SW, Sweileh WM. Worldwide research productivity in the field of electronic cigarette: A bibliometric analysis. BMC Public Health 2014; 14(1): 667. DOI: 10.1186/1471-2458-14-667

[9] Zyoud SeH, Al-Jabi SW, Sweileh WM, Awang R. A bibliometric analysis of toxicology research productivity in Middle Eastern Arab countries during a 10-year period (2003-2012). Health Res Policy Syst 2014; 12(1): 4. DOI: 10.1186/1478-4505-12-4

[10] Sweileh WM, Al-Jabi SW, Sa'ed HZ, Sawalha AF. Bronchial asthma and chronic obstructive pulmonary disease: Research activity in Arab countries. Multidiscip Respir Med 2014; 9(1): 38. DOI: $10.1186 / 2049-6958-9-38$

[11] Falagas ME, Pitsouni EI, Malietzis GA, Pappas G. Comparison of PubMed, Scopus, web of science, and Google scholar: strengths and weaknesses. FASEB J 2008; 22(2): 338-42. DOI: 10.1096/fj.07-9492LSF

[12] Hirsch JE. An index to quantify an individual's scientific research output. Proc Natl Acad Sci USA 2005; 102(46): 16569-72. DOI: 10.1073/pnas.0507655102

[13] Huang C, Wang Y, Li X, et al. Clinical features of patients infected with 2019 novel coronavirus in Wuhan, China. Lancet 2020; 395(10223): 497-506. $10.1016 / \mathrm{S} 0140-6736(20) 30183-5$

[14] Guan W-j, Ni Z-y, Hu Y, et al. Clinical characteristics of coronavirus disease 2019 in China. New Engl J Med 2020; 382(18): 1708-20. DOI: 10.1056/NEJMoa2002032

[15] Wang D, Hu B, Hu C, et al. Clinical characteristics of 138 hospitalized patients with 2019 novel coronavirus-infected pneumonia in Wuhan, China. JAMA 2020; 323(11): 1061-9. DOI: $10.1001 /$ jama.2020.1585

[16] Zhou F, Yu T, Du R, et al. Clinical course and risk factors for mortality of adult inpatients with COVID-19 in Wuhan, China: A retrospective cohort study. Lancet 2020 28; 395(10229): 1054-62. DOI: 10.1016/S0140-6736(20)30566-3

[17] Zhu N, Zhang D, Wang W, et al. A novel coronavirus from patients with pneumonia in China, 2019. New Engl J Med 2020; 382:727-33. DOI: 10.1056/NEJMoa2001017

[18] Chen N, Zhou M, Dong X, et al. Epidemiological and clinical characteristics of 99 cases of 2019 novel coronavirus pneumonia in Wuhan, China: A descriptive study. Lancet 2020; 395(10223): 507-13. DOI: 10.1016/S0140-6736(20)30211-7

[19] Zhou P, Yang X-L, Wang X-G, et al. A pneumonia outbreak associated with a new coronavirus of probable bat origin. Nature 2020; 579(7798): 270-3. DOI: $10.1038 / \mathrm{s} 41586-020-2012-7$

[20] Wu Z, McGoogan JM. Characteristics of and important lessons from the coronavirus disease 2019 (COVID-19) outbreak in China: Summary of a report of 72314 cases from the Chinese Center for Disease Control and Prevention. JAMA 2020; 323(13): 1239-42. DOI: 10.1001/jama.2020.2648

[21] Li Q, Guan X, Wu P, et al. Early transmission dynamics in Wuhan, China, of novel coronavirus-infected pneumonia. New Engl J Med 2020; 382: 1199-207. DOI: 10.1056/NEJMoa2001316

[22] Hoffmann $\mathrm{M}$, Kleine-Weber $\mathrm{H}$, Schroeder $\mathrm{S}$, et al. SARS-CoV-2 cell entry depends on ACE2 and TMPRSS2 and is blocked by a clinically proven protease inhibitor. Cell 2020; 181(2): 271-80. DOI: 10.1016/j.cell.2020.02.052

[23] Lu R, Zhao X, Li J, et al. Genomic characterisation and epidemiology of 2019 novel coronavirus: Implications for virus origins and receptor binding. Lancet 2020; 395(10224): 565-74. DOI: 10.1016/S0140-6736(20)30251-8

[24] Chan JF-W, Yuan S, Kok K-H, et al. A familial cluster of pneumonia associated with the 2019 novel coronavirus indicating person-to-person transmission: A study of a family cluster. Lancet 2020; 395(10223): 514-23. DOI: $10.1016 / \mathrm{S} 0140-6736(20) 30154-9$

[25] $\mathrm{Xu} \mathrm{Z}$, Shi L, Wang $\mathrm{Y}$, et al. Pathological findings of COVID-19 associated with acute respiratory distress syndrome. Lancet Respir Med 2020; 8(4): 420-2. DOI: 10.1016/S2213-2600(20)30076-X

[26] Mehta P, McAuley DF, Brown M, et al. COVID-19: Consider cytokine storm syndromes and immunosuppression. Lancet (London, England). 2020; 395(10229): 1033. DOI: $10.1016 / \mathrm{S} 0140-6736(20) 30628-0$

[27] Wang M, Cao R, Zhang L, et al. Remdesivir and chloroquine effectively inhibit the recently emerged novel coronavirus (2019-nCoV) in vitro. Cell Res 2020; 30(3): 269-71. DOI: $10.1038 /$ s41422-020-0282-0

[28] Wu F, Zhao S, Yu B, et al. A new coronavirus associated with human respiratory disease in China. Nature 2020; 579(7798): 265-9. DOI: 10.1038/s41586-020-2008-3

[29] Holshue ML, DeBolt C, Lindquist S, et al. First case of 2019 novel coronavirus in the United States. New Engl J Med 2020; 382: 929-36. DOI: 10.1056/NEJMoa2001191

[30] Wu C, Chen X, Cai Y, et al. Risk factors associated with acute respiratory distress syndrome and death in patients with 
coronavirus disease 2019 pneumonia in Wuhan, China. JAMA Int Med 2020; 180(7): 934-43. DOI: 10.1001/jamainternmed.2020 .0994

[31] Gautret P, Lagier J-C, Parola P, et al. Hydroxychloroquine and azithromycin as a treatment of COVID-19: results of an open-label non-randomized clinical trial. Int J Antimicrobial Agents 2020; 56(1): 105949. DOI: 10.1016/j.ijantimicag.2020.105949

[32] Cao B, Wang Y, Wen D, et al. A trial of lopinavir-ritonavir in adults hospitalized with severe Covid-19. New Engl J Med 2020; 56(1): 105949 DOI: 10.1056/NEJMoa2001282

[33] Richardson S, Hirsch JS, Narasimhan M, et al. Presenting characteristics, comorbidities, and outcomes among 5700 patients hospitalized with COVID-19 in the New York City area. JAMA 2020; 323(20): 2052-9. DOI: 10.1001/jama.2020.6775

[34] Wrapp D, Wang N, Corbett KS, et al. Cryo-EM structure of the 2019-nCoV spike in the prefusion conformation. Science 2020; 367(6483): 1260-3. DOI: 10.1126/science.abb2507

[35] Zou L, Ruan F, Huang M, et al. SARS-CoV-2 viral load in upper respiratory specimens of infected patients. New Engl J Med 2020; 382(12): 1177-9. DOI: 10.1056/NEJMc2001737

[36] Mao L, Jin H, Wang M, et al. Neurologic manifestations of hospitalized patients with coronavirus disease 2019 in Wuhan,
China. JAMA Neurol 2020; 77(6): 683-90. DOI: 10.1001/jamaneurol.2020.1127

[37] Corman VM, Landt O, Kaiser M, et al. Detection of 2019 novel coronavirus (2019-nCoV) by real-time RT-PCR. Eurosurveillance 2020; 25(3): 2000045. DOI: 10.2807/1560-7917.ES.2020.25.3.2000045

[38] UNESCO: Open access to facilitate research and information on COVID-19. Available at: https://en.unesco.org/covid19/communicationinformationresponse/opensolutions; [Accessed 26, September 2020].

[39] FAIMER: Countries with the most operational medical schools listed in the world directory. Available at: https:/www.faimer.org/research/programs.html; [Accessed 21 August 2020].

[40] Fosci M, Loffreda L, Velten L, Johnson R. Research Capacity strengthening in LMICs: A rapid evidence assessment. United Kingdom: Research Consulting 2019.

[41] Chahrour M, Assi S, Bejjani M, et al. A bibliometric analysis of Covid-19 research activity: A call for increased output. Cureus 2020; 12(3): e7357. DOI: 10.7759/cureus. 7357

[42] Lou J, Tian S-J, Niu S-M, et al. Coronavirus disease 2019: A bibliometric analysis and review. Eur Rev Med Pharmacol Sci 2020; 24(6): 3411-21. 